\title{
Seasonal control of Petermann Gletscher ice-shelf melt by the ocean's response to sea-ice cover in Nares Strait
}

\author{
E. L. SHROYER, ${ }^{1}$ L. PADMAN, ${ }^{2}$ R. M. SAMELSON, ${ }^{1}$ A. MÜNCHOW, ${ }^{3}$ L. A. STEARNS ${ }^{4}$ \\ ${ }^{1}$ College of Earth, Ocean, and Atmospheric Sciences, Oregon State University, Corvallis, OR, USA \\ ${ }^{2}$ Earth \& Space Research, Corvallis, OR, USA \\ ${ }^{3}$ College of Earth, Ocean, and Environment, University of Delaware, Newark, DE, USA \\ ${ }^{4}$ Department of Geology, University of Kansas, Lawrence, KS, USA \\ Correspondence: E. L. Shroyer <eshroyer@coas.oregonstate.edu>
}

\begin{abstract}
Petermann Gletscher drains $\sim 4 \%$ of the Greenland ice sheet (GrIS) area, with $\sim 80 \%$ of its mass loss occurring by basal melting of its ice shelf. We use a high-resolution coupled ocean and sea-ice model with a thermodynamic glacial ice shelf to diagnose ocean-controlled seasonality in basal melting of the Petermann ice shelf. Basal melt rates increase by $\sim 20 \%$ in summer due to a seasonal shift in ocean circulation within Nares Strait that is associated with the transition from landfast sea ice to mobile sea ice. Under landfast ice, cold near-surface waters are maintained on the eastern side of the strait and within Petermann Fjord, reducing basal melt and insulating the ice shelf. Under mobile sea ice, warm waters are upwelled on the eastern side of the strait and, mediated by local instabilities and eddies, enter Petermann Fjord, enhancing basal melt down to depths of $\mathbf{2 0 0} \mathrm{m}$. The transition between these states occurs rapidly, and seasonal changes within Nares Strait are conveyed into the fjord within the same season. These results suggest that long-term changes in the length of the landfast sea-ice season will substantially alter the structure of Petermann ice shelf and its contribution to GrIS mass loss.
\end{abstract}

KEYWORDS: basal melt ice shelf, landfast sea ice, Nares Strait, ocean/glacier interactions, ocean/ice interactions, Petermann Gletscher, sea-ice arching

\section{INTRODUCTION}

Roughly 200 million people around the globe live within $1 \mathrm{~m}$ of the current sea level (Stern, 2006; Milne and others, 2009), making improved projections of the rate of sea-level rise an international priority. The largest source of uncertainty in global sea level change projections comes from poor bounds on the rate of mass loss from the Greenland and Antarctic ice sheets (Shepherd and others, 2012). Over the last two decades, the mass loss rate from Greenland ice sheet (GrIS) has increased rapidly from 1 to $6 \mathrm{~cm}$ equivalent global sea-level rise per 100 years (Vaughan and others, 2013), with the greatest loss occurring at marine-terminating outlet glaciers (Straneo and others, 2013). This loss has been attributed to increased oceanic heat flux to the Greenland's glaciated margins (Holland and others, 2008; Joughin and others, 2012; Straneo and Heimbach, 2013), which has been linked to increased calving rates including collapse of ice shelves and retreat of grounding lines (Pritchard and others, 2009; Pollard and others, 2015). The transfer of ocean heat to a glacier front depends on small-scale physical processes including exchange at fjord mouths, flow over sills and ice-ocean boundary layer physics. A better quantitative understanding of these processes is needed for improved estimates of the contribution of GrlS mass loss to projected sealevel rise (Bindschadler and others, 2013).

Petermann Gletscher (Fig. 1) drains 4\% of the GrIS (Rignot and Kanagaratnam, 2006) and is one of only five Greenland glaciers with a large floating ice shelf remaining today (Münchow and others, 2016). The discharge of ice across the grounding line is $\sim 12 \mathrm{Gta}^{-1}$ (Rignot and Steffen, 2008). Flow speeds average $\sim 1 \mathrm{~km} \mathrm{a}^{-1}$ but are $10-20 \%$ higher in summer than in winter (Nick and others, 2012;
Ahlstrøm and others, 2013). About $80 \%$ of the mass flux across the grounding line is lost through basal melting of the Petermann Gletscher ice shelf (PGIS) (Rignot and Steffen, 2008), the remainder being lost through intermittent calving events (Münchow and others, 2014) and through surface sublimation in winter and meltwater runoff in summer. The PGIS has evidently been relatively stable since the late 1800s, but large calving events in 2010 and 2012 dramatically reduced its length from $85 \mathrm{~km}$ in 2010 to $\sim 50 \mathrm{~km}$ today (Münchow and others, 2014).

The sensitivity of glaciers to large-scale climate variability depends on the details of the environment around their termini (Straneo and others, 2013). Petermann Gletscher terminates in Petermann Fjord which, in turn, opens into Nares Strait, the $\sim 500 \mathrm{~km}$ long passageway separating Ellesmere Island and northwest Greenland, at Hall Basin (Fig. 1). Hall Basin is bounded to the north and south by Robeson and Kennedy channels (each $\sim 30-35 \mathrm{~km}$ wide), respectively. The fjord has a maximum depth near $1100 \mathrm{~m}$ with a sill at its mouth that is $440 \mathrm{~m}$ deep (Johnson and others, 2011).

Nares Strait is an important conduit for freshwater (as ice and liquid) and heat between the Arctic Ocean and the western sub-arctic North Atlantic seas (Kwok, 2005; Münchow, 2016). Annual volume flux through Nares Strait varies between 0.7 and $1.1 \mathrm{~Sv}\left(1 \mathrm{~Sv}=10^{6} \mathrm{~m}^{3} \mathrm{~s}^{-1}\right)$ while the liquid freshwater flux, relative to a salinity of $34.8 \mathrm{~g}$ $\mathrm{kg}^{-1}$, varies between 32 and $54 \mathrm{mSv}$ on annual timescales (Münchow, 2016). The strait's steep terrain channels typically strong southward winds (Samelson and Barbour, 2008). However, exchanges of buoyancy and momentum between the atmosphere and ocean are also affected by 


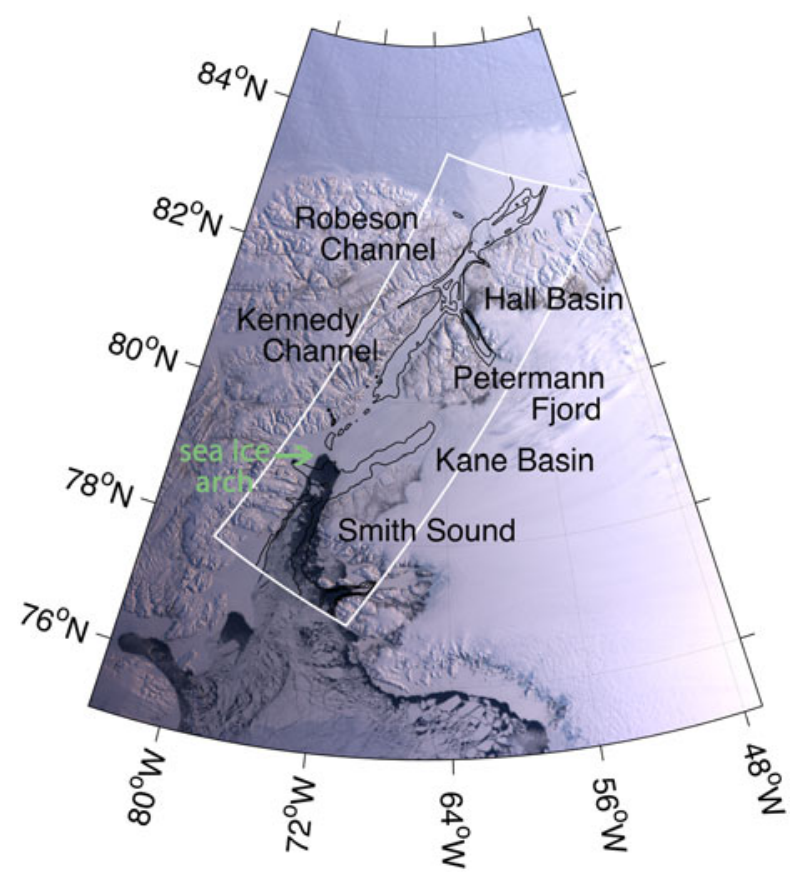

Fig. 1. (a) Surface imagery (MODIS Aqua, 30 April 2015) with the Nares Strait model domain (white box) and bathymetry (black contours show the 250, 500, 750 and $1000 \mathrm{~m}$ isobaths), showing the sea-ice arch at the transition between open water and sea-ice cover at Smith Sound.

sea-ice cover within the strait. The sea-ice cover in Nares Strait regularly transitions from a mobile state during JulyOctober when the sea-ice flux is southward out of the Arctic to a landfast state in winter when a lateral sea-ice arch (Fig. 1) forms across Smith Sound (Kwok, 2005). In some years, sea-ice arches may also form farther north in Robeson and Kennedy Channels (Preußer and others, 2015).

The structural mechanics of sea-ice arches depend on internal stresses within the sea ice; these features have been modeled using both discrete and elastic-visco-plastic formulations (Sodhi, 1977; Hibler and others, 2006; Dumont and others, 2009). When present in Nares Strait, sea-ice arches block the southward flow of sea ice and typically result in landfast ice northward of the arch and polynyas southward of the arch (Fig. 1). Occasionally, ice arches do not form across Nares Strait, and sea ice remains mobile throughout the winter (e.g., in 2007, 2009, 2010). Without an ice arch the annual mean liquid freshwater transport increases by a factor of 2-3 (Münchow and others, 2016), while sea-ice flux increases by a factor of 5-10 compared with years with an ice arch (Kwok and others, 2010; P. Ryan and A. Münchow, unpublished information).

Shroyer and others (2015) used a high-resolution ocean model coupled to idealized sea-ice states to identify the processes by which winter landfast sea-ice cover affect the ocean circulation within Nares Strait. That study did not include Petermann Fjord, but it did suggest ways in which processes within Nares Strait might influence the flux of ocean heat into the fjord as a source of melting for PGIS. Here, we use an improved, fully coupled ocean and seaice regional model augmented by a fixed-geometry thermodynamically coupled ice shelf to show how the ocean's response to sea-ice conditions in Nares Strait seasonally modulates basal melting of PGIS.

\section{METHODS}

We used the MIT general circulation model (Marshall and others, 1997) to configure a regional ocean model of Nares Strait and Petermann Fjord (Fig. 1) coupled to a dynamic/ thermodynamic sea-ice model (Losch and others, 2010) and a thermodynamic ice shelf with fixed geometry (Losch, 2008). The $240 \times 560 \times 60$ model cells were configured into a variable grid resolution that ranged from sub-kilometer in the vicinity of Petermann Fjord to $\sim 1.5 \mathrm{~km}$ near the model boundaries with $10 \mathrm{~m}$ vertical resolution in the upper $500 \mathrm{~m}$ smoothly varying to $50 \mathrm{~m}$ resolution below $750 \mathrm{~m}$ depth. The model bathymetry merged data from the International Bathymetric Chart of the Arctic Ocean (IBCAO) version 3.0 (Jakobsson and others, 2012) with recent multibeam data from the outer portion of Petermann Fjord (Personal communication from M. Jakobsson, L. Mayer, and A. Mix, 2015). Model boundary conditions, surface forcing, spin-up, and horizontal and vertical mixing schemes follow directly from Shroyer and others (2015) with the exception that all atmospheric fields varied spatially over the domain in the simulation presented here.

Relative to the previous model implementation (Shroyer and others, 2015), the present model includes a more realistic representation of Petermann Fjord based on the new multibeam data, a sea-ice state that transitions from landfast to mobile over the simulation year and a thermodynamically coupled ice shelf. The ice shelf geometry is uniform in the across-fjord direction with an along-fjord profile based on the pre-2010 geometry (Münchow and others, 2014), with ice draft $=-450 \mathrm{~m} \times\{1+\tanh \{(x-80 \mathrm{~km}) / 35 \mathrm{~km}\}\}-$ $35 \mathrm{~m}$. The ice shelf is smooth and lacks the small-scale basal topography and channels that have been previously reported (Rignot and Steffen, 2008; Münchow and others, 2014). Thermodynamic coupling relies on a two equation model of interactions between the ocean and ice shelf (Holland and Jenkins, 1999) with a heat transfer coefficient of $4 \times 10^{-5} \mathrm{~m} \mathrm{~s}^{-1}$.

The ice-shelf model outputs the heat flux $\left(U_{q}, \mathrm{~W} \mathrm{~m}^{-2}\right)$ between the ocean and the ice shelf. Heat fluxes were converted to melt rates $\left(q, \mathrm{~m} \mathrm{a}^{-1}\right)$ using the density of ice $\left(\rho_{\text {ice }}=930 \mathrm{~kg} \mathrm{~m}^{-3}\right)$ and the latent heat of fusion $(L=3.34 \times$ $10^{5} \mathrm{~J} \mathrm{~kg}^{-1}$ ) according to

$$
q=\frac{J_{q}}{\rho_{\text {ice }} L} .
$$

The total net melt of the ice shelf was calculated as the weighted integral over the modeled ice-shelf area, $s \times$ $\int \rho_{\text {ice }} q d A_{\text {ice shelf }}$, where $s=0.78$ is the ratio of the area of the physical ice shelf $\left(1250 \mathrm{~km}^{2}\right)$ to the modeled ice shelf $\left(1608 \mathrm{~km}^{2}\right)$. The difference in ice-shelf area can be attributed to the idealized ice-shelf geometry combined with the smoothing of the bathymetry and coastlines in the merged IBCAO/multibeam product.

Fjord heat budget terms (given in the text as percentages relative to one another) were calculated relative to the average temperature in time and space $(\bar{T})$. The volumeintegrated heat tendency within the fjord is $\partial / \partial t \int \rho_{\mathrm{o}} c_{p}(T-$ $\bar{T}) d V_{\text {fjord }}$ where $\rho_{o}$ is the reference ocean density, $c_{p}$ the heat capacity, $T$ the model temperature and $V_{\text {fjord }}$ extends from the sill to the grounding line. Heat transported over the sill is $\int u \times \rho_{\mathrm{o}} c_{p}(T-\bar{T}) d A_{\text {sill }}$ where $u$ is the model across-strait velocity and $A_{\text {sill }}$ the vertical cross-sectional area across the sill. The heat exchange between the ocean 
and the ice shelf $\left(\int J_{q} d A_{i c e}\right)$ uses heat flux $\left(J_{q}\right)$ output from the model integrated over the ice-shelf area $\left(A_{\text {ice }}\right)$.

\section{OCEAN RESPONSE TO SEA-ICE COVER IN NARES STRAIT}

Observations indicate that ocean circulation within Nares Strait shifts seasonally in response to the establishment and breakdown of the Smith Sound sea-ice arch (Rabe and others, 2012). Our model reproduces this observed seasonal shift in ocean structure as a result of a simple Ekman adjustment to the different surface stresses (Shroyer and others, 2015), which change from a mean northward sea-ice drag in winter to a mean southward wind stress in summer. Under landfast sea ice (Fig. 2a), the northward sea-ice drag causes eastward Ekman transport of relatively fresh, cool near-surface waters and reduces near-surface flow, resulting in a subsurface maximum in the southward flow of relatively warm and salty intermediate-depth water that is offset toward the western side of the strait. Under mobile sea-ice conditions (Fig. 2b), the southward wind stress causes westward surface Ekman transport that displaces the fresh, cool layer to the west, which drives upwelling of relatively warm, salty deep water along the eastern side of the strait and results in a mean southward flow that is generally surface intensified and distributed across the center of the strait (Shroyer and others, 2015). Thus, the distribution of heat and salt within Nares Strait shifts in response to the prevailing sea-ice conditions and winds.

Under mobile sea ice, the ocean circulation also develops meanders and eddies south of Robeson Channel (Fig. 3a, b). At the mouth of Petermann Fjord, these eddies appear to stabilize temporarily before propagating farther south through Nares Strait. An eddy similar to the simulated features has been observed previously in opportunistic field sampling and coincident remote sensing (Johnson and others, 2011). In our model, the strong cyclonic flow associated with these eddies leads to enhanced exchange at the mouth to Petermann Fjord during summer (Fig. 3c, d).

\section{SEASONAL CHANGES IN THE CONNECTION BETWEEN NARES STRAIT AND PETERMANN FJORD}

The seasonal changes in the model temperature and salinity at the mouth of Petermann Fjord penetrate into the fjord. The

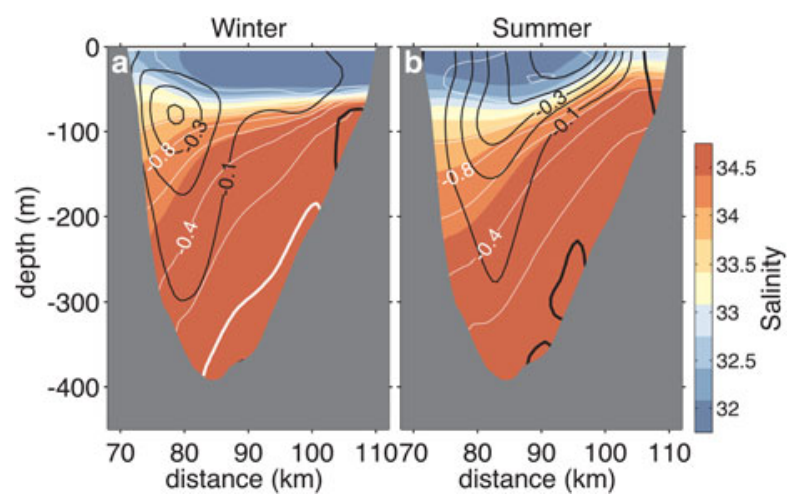

Fig. 2. Time mean salinity (color shading), temperature (white contours plotted every $0.2{ }^{\circ} \mathrm{C}$ with zero shown in bold) and southward velocity (black contours plotted every $2 \mathrm{~cm} \mathrm{sec}^{-1}$ with zero shown in bold) at Kennedy Channel over (a) winter and (b) summer periods (as defined in Fig. 4b). volume averaged temperature and salinity within the fjord are, respectively, $0.05^{\circ} \mathrm{C}$ and $0.20 \mathrm{~g} \mathrm{~kg}^{-1}$ higher in summer than in winter, reflecting seasonality in the distribution of water properties in Nares Strait. The flow at the fjord mouth in summer is primarily characterized by a lateral inflow and outflow on opposing sides of the fjord in the direction of Kelvin wave propagation, while in winter the lateral and vertical structure of the inflow and outflow is more complex, with multiple reversals across the mouth. In both seasons, the inflow temperature and salinity are almost always greater than the outflow temperature and salinity, with the inflow of warm, salty deep water being balanced by outflow of cooler, fresher water higher in the water column, consistent with observations reported by Johnson and others (2011). In winter, the inflow is $0.3^{\circ} \mathrm{C}$ warmer and $0.15 \mathrm{~g} \mathrm{~kg}^{-1}$ saltier than the outflow. In summer, the inflow is $0.4^{\circ} \mathrm{C}$ warmer and $0.25 \mathrm{~g} \mathrm{~kg}^{-1}$ saltier than the outflow. Seasonality in temperature and salinity is pronounced above $200 \mathrm{~m}$, with summertime means $\sim 0.4^{\circ} \mathrm{C}$ warmer and $\sim 0.5$ saltier than wintertime means (Fig. 4c, d). Since data from the fjord are only available for summer, the seasonal change within Petermann Fjord has not been verified observationally. However, seasonality in the simulated conditions is consistent with the ocean circulation observed from several years of moorings farther downstream within Nares Strait (Münchow, 2016).

Our simulation also suggests an enhanced exchange in summer due to eddy-induced circulation at the mouth of Petermann Fjord. Strongly pulsed inflow events propagate from Nares Strait deep into the fjord. While these events occur in both winter and summer, they happen more often in summer, extending under the ice shelf (Fig. 3d), consistent with the modeled seasonality of eddies at the mouth of Petermann Fjord. Consequently, the glacierward transport into the fjord is larger in summer than in winter (Fig. 3d), implying that water entering the fjord is recirculated back to Nares Strait more quickly in summer. We estimate an exchange timescale by dividing fjord water volume by the glacier-ward transport at the sill and find that it takes $\sim 60$ days in summer and $\sim 100$ days in winter to flush the fjord (Fig. 3c). These short timescales suggest that seasonal changes in Nares Strait water property distributions can propagate into Petermann Fjord to affect PGIS within the same season.

\section{BASAL MELT RATES FOR PETERMANN GLETSCHER ICE SHELF}

The simulated, seasonally-varying sea-ice conditions outside of the fjord alter oceanic heat transport into Petermann Fjord, leading to enhanced basal melt of the PGIS in summer. The summer average of the modeled melt rate averaged over the entire base of PGIS is $16.6 \mathrm{~m} \mathrm{a}^{-1}, \sim 20 \%$ greater than the winter average of $13.8 \mathrm{~m} \mathrm{a}^{-1}$ (Fig. 4b). The seasonal change is primarily restricted to the outer portion of PGIS where its ice draft is $<200 \mathrm{~m}$; in this region the summertime median melt rate of $13.5 \mathrm{~m} \mathrm{a}^{-1}$ is almost twice that of the wintertime value of $7.3 \mathrm{~m} \mathrm{a}^{-1}$. For PGIS draft $<100 \mathrm{~m}$, the melt rates are typically $>10 \mathrm{ma}^{-1}$ in summer and $<5 \mathrm{~m}$ $\mathrm{a}^{-1}$ in winter.

On timescales less than a few weeks, changes in heat content within the fjord are almost balanced by flow over the sill. However, over longer timescales the heat transported across the sill is within $10-20 \%$ of the heat lost to the ice 

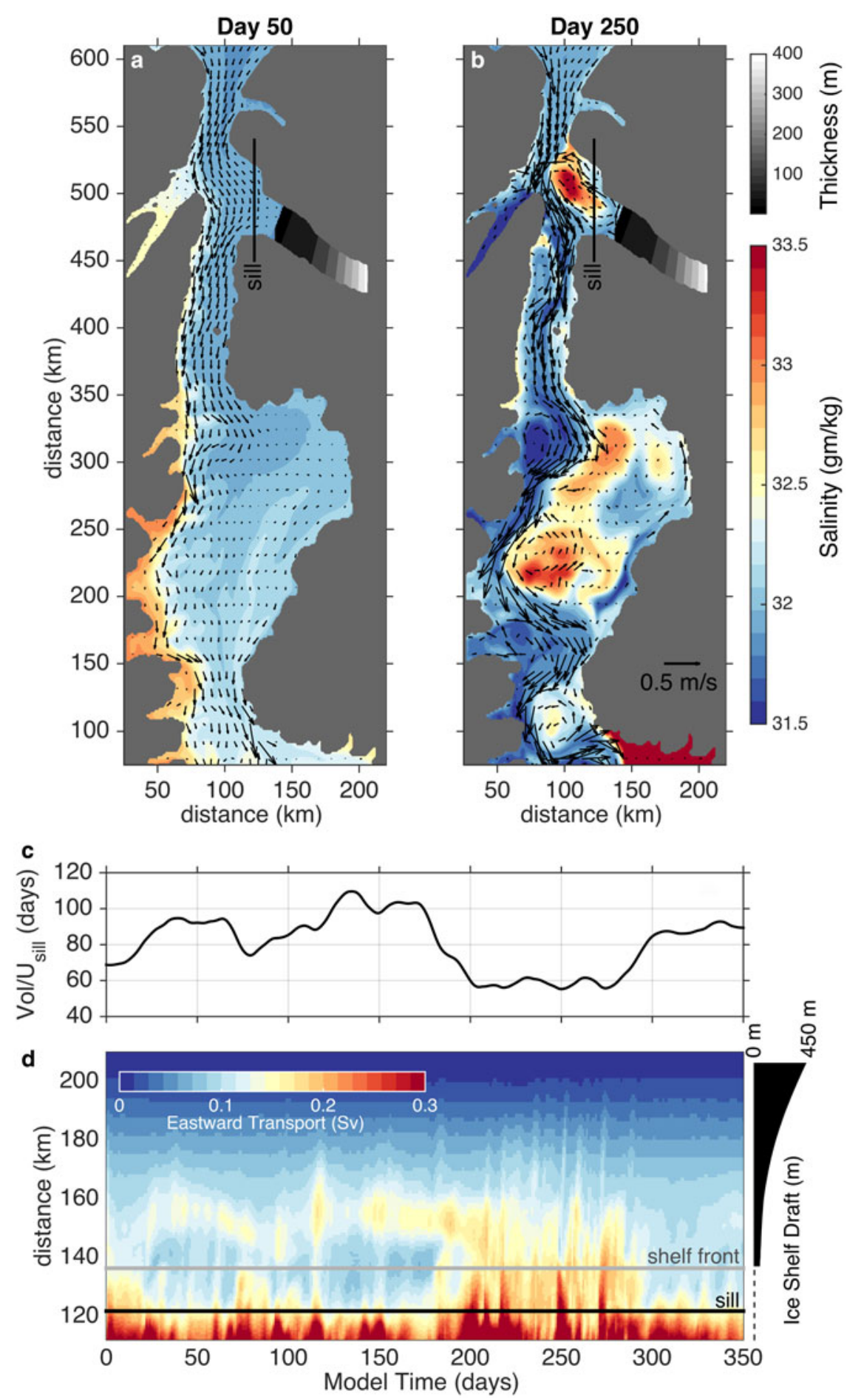

Fig. 3. Model fields on (a) day 50 (landfast sea ice) and (b) day 250 (mobile sea ice). (a, b) Salinity at $15 \mathrm{~m}$ (color shading), ice-shelf thickness (grey scale shading) and ocean currents at $45 \mathrm{~m}$ (vectors). (c) Fjord exchange timescale calculated by dividing the volume glacier-ward of the sill at $\sim 122 \mathrm{~km}$ by the eastward volume transport averaged between the sill and shelf front (black and grey lines in panel (d) and smoothed over 15 days. (d) Eastward volume transport as a function of time and east-west distance. Sill and shelf front locations are indicated. The mean iceshelf draft is shown to the right of panel $(d)$.

shelf, with an excess of heat transported into the fjord over that lost to PGIS in winter, and an excess lost to PGIS in summer. Seasonal changes within the fjord occur concurrently with the reduction in sea-ice area and transition to a mobile sea-ice state within Robeson Channel and Hall Basin (Fig. 4a). Sea-ice motion in this region follows the breakup of the lateral sea-ice arch across Smith Sound.

The model's scaled integrated mass loss is $18 \mathrm{Gt} \mathrm{a}^{-1}$ in the annual mean (Fig. 4b). This value is $\sim 30 \%$ higher than the total observed integrated melt of $14 \mathrm{Gt} \mathrm{a}^{-1}$ that combines a steady state integrated melt of $\sim 10 \mathrm{Gt} \mathrm{a}^{-1}$ (i.e., ice flux crossing the grounding line minus net surface mass loss and calving flux) with a non-steady thinning of $\sim 4 \mathrm{Gta}^{-1}$ (Münchow and others, 2014). The modeled melt rates, which in the annual mean range from 1 to $33 \mathrm{~m} \mathrm{a}^{-1}$ with a median of $13 \mathrm{~m} \mathrm{a}^{-1}$, are similar to point estimates of the steady-state melt rate given by Rignot and Steffen (2008), which range from $\sim 0$ to $30 \mathrm{~m} \mathrm{a}^{-1}$, and the net melt rate of 

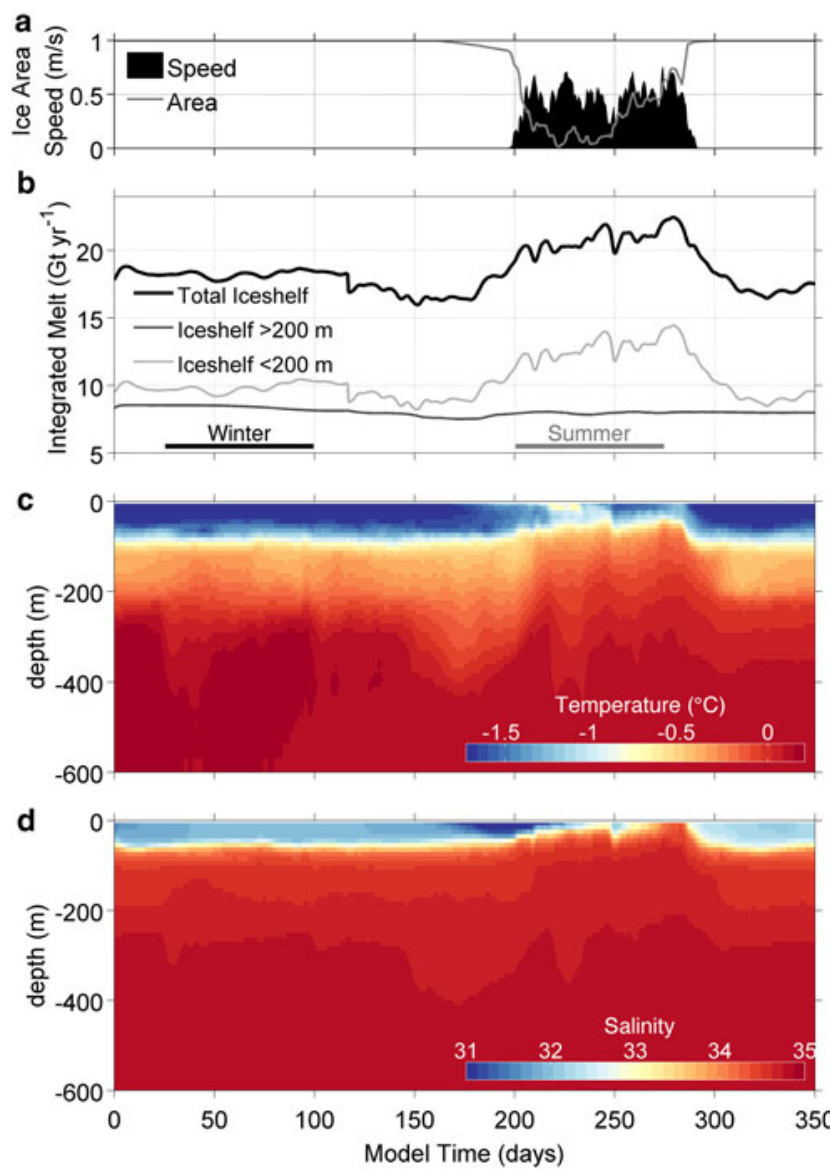

Fig. 4. (a) Average sea-ice concentration (grey) and sea-ice speed (black) in northern Nares Strait. (b) Total net melt (black), net melt for ice-shelf thickness $<200 \mathrm{~m}$ (light grey) and net melt for iceshelf thickness $>200 \mathrm{~m}$ (dark grey). Time series of (c) temperature and (d) salinity averaged within Petermann Fjord.

$13 \mathrm{~m} \mathrm{a}^{-1}$ estimated by Münchow and others (2014). Two potential sources of discrepancies between the modeled and observed integrated melt are our simplified parameterization of ocean/ice thermodynamic exchanges and the model's idealized ice-shelf geometry, which lacks the basal channels and crevasses that may have a significant influence on net basal melt.

\section{DISCUSSION: IMPLICATIONS FOR LONG-TERM STABILITY OF PGIS}

The summertime increase in PGIS basal melting arises in the model through a transition in ocean circulation associated with the collapse of the sea-ice arch across Smith Sound that facilitates the transition from landfast to mobile sea ice throughout Nares Strait. The underlying physical mechanism, oceanic heat advection by the Ekman response to different surface stresses (the southward winds and northward ice drag), is robust and should be relatively independent of the details of model implementation. Although the fixedgeometry ice-shelf representation used here does not allow direct modeling of the quasi-equilibrium balances that determine the large-scale structure of the ice shelf, the results nonetheless suggest that the long-term stability of the PGIS may relate to the regular establishment of landfast sea ice within Nares Strait. For $\sim 8$ months of a typical year, the stress exerted by landfast ice on the ocean will displace relatively cool, fresh water in Nares Strait to the east and into the fjord. Melting of the shallow-draft outer portions of the ice shelf is reduced, both by the lack of inflowing ocean heat at that depth and by the buoyant plume flow originating from rapid basal melting under deeper ice closer to the grounding line.

These results also suggest a role for this mechanism in preconditioning PGIS for large calving events, such as those observed in 2010 and 2012 (Fig. 5b). Sea ice in the Hall Basin region of Nares Strait experienced extended periods of low summer ice concentration in preceding years (Fig. 5b). Our simulations suggest that these sea-ice anomalies would be associated with penetration of warmer upperocean waters into the fjord over a longer time period. In turn, this would cause increased thinning of PGIS. We hypothesize that this thinning could weaken the ice shelf, increasing the probability for calving events in the following years after the winter sea ice was removed from the fjord (e.g., Fig. 5a).

If Arctic sea-ice volume continues to decline as climate models predict (Wang and Overland, 2012), thinner ice entering Nares Strait may be less likely to arch, lengthening the mobile ice season and increasing the period of elevated basal melt. Unless this increase is offset by a larger ice flux across the grounding line, PGIS will thin and calving may occur more frequently (e.g., as suggested by Fig. 5 and similar to changes underway in Antarctica (Rignot and others, 2014)). Our results indicate that increased melt by this mechanism will be limited to regions with ice-shelf draft $<\sim 200 \mathrm{~m}$, suggesting that PGIS may reach a new quasi-equilibrium length $\sim 40-45 \mathrm{~km}$ from the terminus where the PGIS draft is on average $200 \mathrm{~m}$ thick. Other changes, such as a continuation of the observed warming of the deep water in Nares Strait and Petermann Fjord (Johnson and others, 2011; Münchow and others, 2011), could increase melt rates under thicker portions of PGIS to the point where the calving front retreats to the grounding line, as already seen for other Greenland glaciers (Motyka and others, 2011; Mouginot and others, 2015).

The modeled seasonality demonstrates the close ties between the multiple components (atmosphere, sea ice, ocean and ice sheet) of the climate system. This example also highlights the challenges in forecasting GrlS mass balance associated with ocean/ice interactions at the marine margins, in that forecasts require sea-ice dynamics, exterior to the fjord and ocean instabilities under variable surface forcing to be reasonably represented or parameterized. Models need to accurately represent tightly coupled changes in all system components at the small length scales characteristic of fjords, and the short timescales of ocean instabilities that provide heat to fjords, tidewater glacier faces and the remaining glacial ice shelves.

\section{ACKNOWLEDGEMENTS}

This work was supported by the National Science Foundation (Grant ARC-1108463) and the National Aeronautics and Space Administration (grant No. NNX15AL77 G and NNX13AP60G). We acknowledge high-performance computing support from Yellowstone (ark:/85065/d7wd3xhc) provided by NCAR's Computational and Information Systems Laboratory, sponsored by the National Science Foundation. We thank Martin Jakobsson (Stockholm University), Larry Mayer (University of New Hampshire) and Alan Mix (Oregon State University) for use of the multibeam dataset for bathymetry in the vicinity of 
a

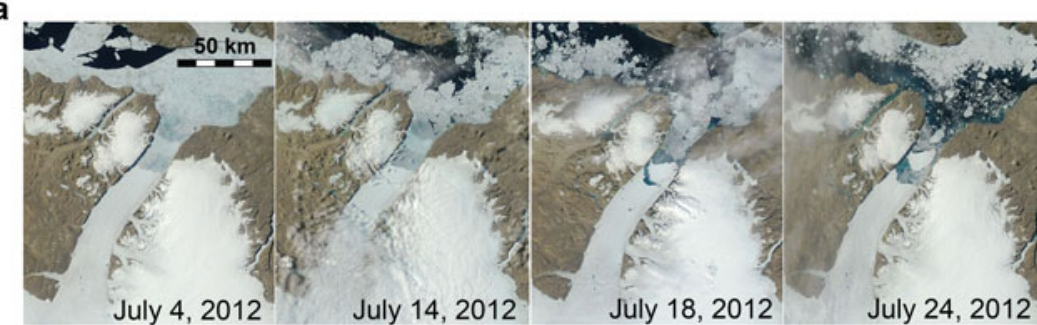

b

Sea Ice Area Time Record

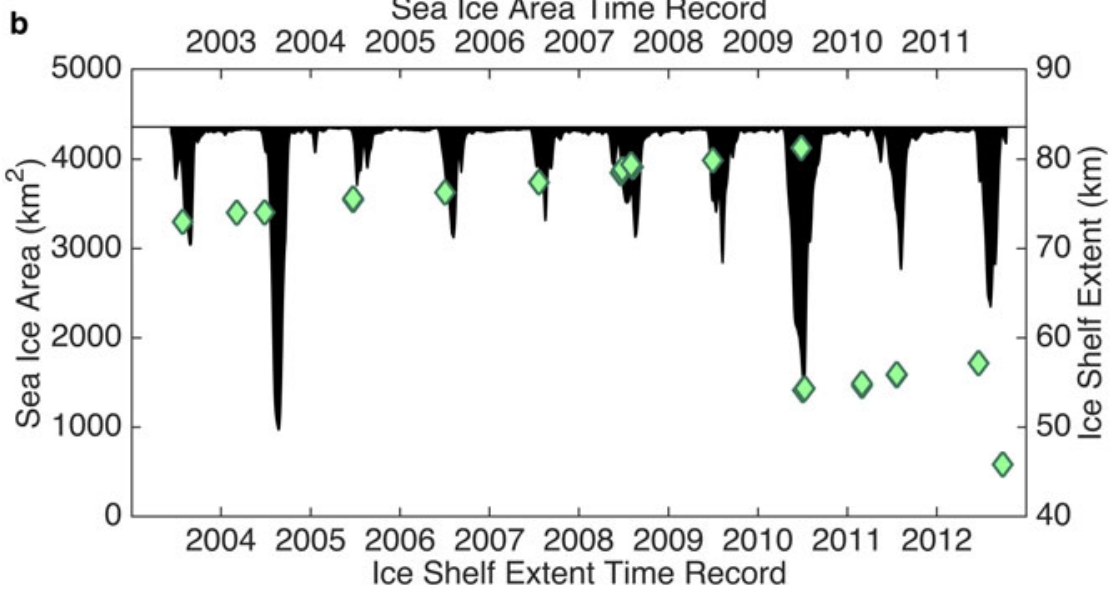

Fig. 5. (a) Sequence of MODIS images showing the 2012 Petermann Gletscher calving event that occurred coincident with clearing of sea ice from the fjord and strait. (b) Sea-ice area (black shading, upper and left axes) and Petermann ice-shelf extent (green diamonds, lower and right axes from (Münchow and others, 2014)). Sea-ice area is calculated from $12.5 \mathrm{~km}$ gridded AMSR-E sea-ice concentration within Hall Basin. Note that time series for sea-ice area and ice-shelf extent are shifted by 1 year. Low sea-ice concentration occurred in 2009 and 2011, i.e., years preceding large calving events in 2010 and 2012.

Petermann Fjord. R.M.S. is grateful to Prof. O. T. Gudmestad and the Universitet i Stavanger for their hospitality during a sabbatical visit. We also acknowledge the helpful comments from two anonymous reviewers.

\section{REFERENCES}

Ahlstrøm AP and 13 others (2013) Seasonal velocities of eight major marine-terminating outlet glaciers of the Greenland ice sheet from continuous in situ GPS instruments. Earth Syst. Sci. Data 5(2), 277-287 (doi: 10.5194/essd-5-277-2013)

Bindschadler RA and 27 others (2013) Ice-sheet model sensitivities to environmental forcing and their use in projecting future sea level (the SeaRISE project). J. Glaciol. 59(214), 195-224 (doi: 10.3189/2013JoG12J125)

Dumont D, Gratton Y and Arbetter TE (2009) Modeling the dynamics of the North Water polynya ice bridge. J. Phys. Oceanogr. 39(6), 1448-1461

Hibler WD, Hutchings JK and Ip CF (2006) Sea-ice arching and multiple flow states of Arctic pack ice. Ann. Glaciol. 44(1), 339-344

Holland DM and Jenkins A (1999) Modeling thermodynamic iceocean interactions at the base of an ice shelf. J. Phys. Oceanogr. 29(8), 1787-1800 (doi: 10.1175/1520-0485(1999) 029<1787:MTIOIA > 2.0.CO;2)

Holland DM, Thomas $\mathrm{RH}$, de Young $\mathrm{B}$, Ribergaard $\mathrm{MH}$ and Lyberth B (2008) Acceleration of Jakobshavn Isbræ triggered by warm subsurface ocean waters. Nat. Geosci. 1(10), 659-664 (doi: 10.1038/ngeo316)

Jakobsson M and 30 others (2012) The international bathymetric chart of the Arctic Ocean (IBCAO) Version 3.0. Geophys. Res. Lett. 39(12) (doi: 10.1029/2012GL052219)
Johnson HL, Münchow A, Falkner KK and Melling H (2011) Ocean circulation and properties in Petermann Fjord, Greenland. J. Geophys. Res. 116(C), 1003

Joughin I, Alley RB and Holland DM (2012) Ice-sheet response to oceanic forcing. Science. 338(6111), 1172-1176 (doi: 10.1126/science.1226481)

Kwok R (2005) Variability of Nares Strait ice flux. Geophys. Res. Lett. 32(24), 1-4 (doi: 10.1029/2005GL024768)

Kwok R, Pedersen LT, Gudmandsen P and Pang SS (2010) Large sea ice outflow into the Nares Strait in 2007. Geophys. Res. Lett. 37(3) (doi: 10.1029/2009GL041872)

Losch M (2008) Modeling ice shelf cavities in a z coordinate ocean general circulation model. J. Geophys. Res. Ocean. 113(8) (doi: 10.1029/2007JC004368)

Losch M, Menemenlis D, Campin JM, Heimbach P and Hill C (2010) On the formulation of sea-ice models. Part 1: effects of different solver implementations on parameterizations. Ocean Model. 33, 129-144

Marshall J, Adcroft A, Hill C and Perelman L (1997) A finite-volume, incompressible Navier Stokes model for studies of the ocean on parallel computers. J. Geophys. Res. 102, 5753-5766

Milne GA, Gehrels WR, Hughes CW and Tamisiea ME (2009) Identifying the causes of sea-level change. Nat. Geosci. 2(7), 471-478 (doi: 10.1038/ngeo544)

Motyka RJ and 5 others (2011) Submarine melting of the 1985 Jakobshavn Isbræ floating tongue and the triggering of the current retreat. J. Geophys. Res. 116(F01007), 10.1029/2009JF001632

Mouginot J and 7 others (2015) Fast retreat of Zachariæ Isstrøm, northeast Greenland. Science (80). http://science.sciencemag. org/content/early/2015/11/11/science.aac7111.abstract

Münchow A (2016) Volume and freshwater flux observations from Nares Strait to the west of Greenland at daily time scales from 2003 to 2009. J. Phys. Oceanogr. 46(1), 141-157 (doi: 10.1175/JPO-D-15-0093.1) 
Münchow A, Falkner K, Melling H, Rabe B and Johnson H (2011) Ocean warming of Nares Strait bottom waters off Northwest Greenland, 2003-2009. Oceanography 24(3), 114-123 (doi: 10.5670/oceanog.2011.62)

Münchow A, Padman L and Fricker HA (2014) Interannual changes of the floating ice shelf of Petermann Gletscher, North Greenland, from 2000 to 2012. J. Glaciol. 60(221), 489-499 (doi: 10.3189/2014JoG13J135)

Münchow A, Washam AP, Padman L and Nicholls K (2016) The ice shelf of Petermann Gletscher, North Greenland and its connection to Arctic and Atlantic oceans. Oceanography submitted

Nick FM and 9 others (2012) The response of Petermann Glacier, Greenland, to large calving events, and its future stability in the context of atmospheric and oceanic warming. J. Glaciol. 58 (208), 229-239 (doi: 10.3189/2012JoG11J242)

Pollard D, DeConto RM and Alley RB (2015) Potential Antarctic Ice Sheet retreat driven by hydrofracturing and ice cliff failure. Earth Planet. Sci. Lett. 412, 112-121 (doi: 10.1016/j.epsl.2014.12.035)

Preußer A, Heinemann G, Willmes S and Paul S (2015) Multidecadal variability of polynya characteristics and ice production in the North Water Polynya by means of passive microwave and thermal infrared satellite imagery. Remote Sensing 7(12) (doi: 10.3390/rs71215807)

Pritchard HD, Arthern RJ, Vaughan DG and Edwards LA (2009) Extensive dynamic thinning on the margins of the Greenland and Antarctic ice sheets. Nature 461(7), 971-975

Rabe B, Münchow A, Johnson HL and Melling H (2012) Geostrophic currents and freshwater fluxes through Nares Strait to the west of northern Greenland. J. Marine Res. 70(4), 603-640 http://www. ingentaconnect.com/content/jmr/jmr/2012/00000070/00000004/ art00002

Rignot E and Kanagaratnam P (2006) Changes in the velocity structure of the Greenland Ice Sheet. Science 311 (80). (101126/ science.1121381), 986-990

Rignot E and Steffen K (2008) Channelized bottom melting and stability of floating ice shelves. Geophys. Res. Lett. 35(2) (doi: 10.1029/2007GL031765)
Rignot E, Mouginot J, Morlighem M, Seroussi H and Scheuchl B (2014) Widespread, rapid grounding line retreat of Pine Island, Thwaites, Smith, and Kohler glaciers, West Antarctica, from 1992 to 2011. Geophys. Res. Lett. 41(10), 3502-3509 (doi: 10.1002/2014GL060140)

Samelson RM and Barbour PL (2008) Low-level jets, orographic effects, and extreme events in nares strait: a model-based mesoscale climatology. Mon. Weather Rev. 136(12), 4746-4759 (doi: 10.1175/2007MWR2326.1)

Shepherd A and 45 others (2012) A reconciled estimate of ice-sheet mass balance. Science (80). 338(6111), 1183-1189 http:// science.sciencemag.org/content/338/6111/1183.abstract

Shroyer EL, Samelson RM, Padman L and Münchow A (2015) Modeled ocean circulation in Nares Strait and its dependence on landfast-ice cover. J. Geophys. Res. Ocean. 120(12), 79347959 (doi: 10.1002/2015JC011091)

Sodhi DS (1977) Ice arching and the drift of pack ice through restricted channels. CRREL Rep. 77(18), 1-11

Stern N (2006) The economics of climate change. Stern Rev., 662 (doi: 10.1257/aer.98.2.1)

Straneo F and Heimbach P (2013) North Atlantic warming and the retreat of Greenland's outlet glaciers. Nature 504(7478), 36-43 https://doi.org/10.1038/nature12854

Straneo F and 15 others (2013) Challenges to understanding the dynamic response of Greenland's marine terminating glaciers to oceanic and atmospheric forcing. Bull. Am. Meteorol. Soc. 94(8), 1131-1144 (doi: 10.1175/BAMS-D12-00100.1)

Vaughan DG and 13 others (2013) Observations: Cryosphere. in Climate Change 2013 - The Physical Science Basis: Working Group I Contribution to the Fifth Assessment Report of the Intergovernmental Panel on Climate Change. Cambridge University Press, Cambridge, 317-382 (doi: 10.1017/ CBO9781107415324.012)

Wang M and Overland JE (2012) A sea ice free summer Arctic within 30 years: an update from CMIP5 models. Geophys. Res. Lett. 39 (18), n/a-n/a (doi: 10.1029/2012GL052868) 